\title{
How US-made rules shape internet governance in China
}

\author{
Natasha Tusikov \\ Department of Social Science, York University, Toronto, Canada
}

Published on 30 Jun 2019 | DOI: 10.14763/2019.2.1408

\begin{abstract}
The United States is shaping Chinese internet governance by embedding US-preferred standards for the protection of intellectual property rights within Chinese platforms. As a result, the China-based Alibaba e-commerce giant has instituted US-drafted rules to deal with the sale of counterfeit goods. To explain this development, the article introduces the concept of compliance-plus regulation, which draws from regulatory theory and socio-legal studies to account for the state coercively pressuring one set of private actors (platforms) to regulate "voluntarily" on behalf of another set of private actors (rights holders). Drawing upon an analysis of documents from the US government, US industry, and Alibaba, the article finds that while economic pressure on Alibaba was a central factor, there are also common economic interests between Alibaba and US and European rights holders.
\end{abstract}

Keywords: Internet governance, Intellectual property, Platforms, China, United States of America

\section{Article information}

Received: 01 Mar 2019 Reviewed: 29 May 2019 Published: 30 Jun 2019

Licence: Creative Commons Attribution 3.0 Germany

Funding: Funding for this research was provided by the Social Science and Humanities Research

Council of Canada.

Competing interests: The author has declared that no competing interests exist that have influenced the text.

URL: http://policyreview.info/articles/analysis/how-us-made-rules-shape-internet-governance-china

Citation: Tusikov, N. (2019). How US-made rules shape internet governance in China. Internet Policy Review, 8(2). DOI: 10.14763/2019.2.1408

This paper is part of Transnational materialities, a special issue of Internet Policy Review guest-edited by José van Dijck and Bernhard Rieder.

\section{INTRODUCTION}

The rapid growth of Chinese internet companies over the past decade has generated friction between the United States and China (see e.g. Plantin \& de Seta, 2019). One key issue is China's practice of restricting or blocking access to popular US sites, platforms, and applications like Facebook, Twitter, Instagram and Snapchat. The Chinese government has strategically 
cultivated its own national technology champions by protecting domestic firms from foreign competitors, enacting policy incentives, and granting government contracts, which despite the imposition of a strict censorship regime has resulted in a symbiotic partnership between the Chinese government and its commercial internet firms (Jiang \& Fu, 2018; see also Shen, 2016). As a result, Chinese platforms have grown rapidly with the emergence of dominant firms: Baidu, the search giant, Tencent, which operates the popular WeChat social media platform, and the Alibaba Group (hereafter Alibaba), whose Taobao and Tmall platforms are the dominant retail marketplaces in China. A "platform" here refers to a programmable digital architecture that facilitates interactions between users that is fueled by data and governed through user agreements (Van Dijck, Poell, \& Waal, 2018, p. 9).

Trade tensions between China and the United States sharply increased in 2017 with the Trump administration's imposition of tariffs on a range of Chinese-made goods to which China responded with tariffs against American goods (Meltzer \& Shenai, 2019). In what some characterise as the beginning of a "technology cold war" (see Muñiz, 2019), as part of the USChina trade dispute, the US government has also targeted Chinese technology companies, especially Huawei, the massive manufacturer of telecommunications equipment, including consumer electronics and hardware for wireless networks, over concerns that Huawei may facilitate spying by the Chinese government on the United States. In May 2019, President Trump signed an executive order designating Huawei a national security risk (see Muñiz, 2019), which means US firms must seek government permission before doing business with the company and, as a result, companies like Google have ceased doing business with Huawei (see Sottek, 2019). Restrictions on technology companies by both the US and Chinese governments raise fears of a fracturing of global supply chains, particularly as companies are pushed to side with one country over the other (see Muñiz, 2019).

While the US-China trade dispute has important short- and long-term economic ramifications for both countries and the global economy (see Meltzer \& Shenai, 2019), there are also larger technological and political issues at play. For the United States, fears about its declining hegemony and China's ascendance are, at least in part, driving its trade dispute with China (see Meltzer \& Shenai, 2019; Min-hyung, 2019). China, meanwhile, has a series of strategic projects to rapidly increase its technological capabilities to challenge US hegemony (see Min-hyung, 2019). One of these projects is China's "Made in China 2025" plan, an ambitious ten-year industrial development project with the goal of making China a manufacturing superpower that will dominate global markets in advanced technologies like robotics, autonomous vehicles, and artificial intelligence (Min-hyung, 2019, p. 34; see Laskai, 2018). President Trump explicitly stated that US tariffs are intended to impede the Made in China 2025 programme (Hopewell, 2018). By imposing tariffs and targeting Chinese technology companies, the United States calculates that it will maintain its dominance within the global economy, a strategy that many analysts contend will backfire (see Hopewell, 2018).

Despite the ongoing debate of a decline in US hegemony with the balance of power shifting toward China (e.g., Layne, 2018), many scholars contend that the structural power of the US market remains strong (see e.g., Gilli \& Gilli, 2019; Schwartz, 2017; Tooze, 2019). Structural power, as theorised by the British international political economist Susan Strange, is "the power to shape and determine the structures of the global political economy" (Strange, 1994, pp. 24-25). A key aspect of American global economic power is its ability to exert "control over a disproportionate share of global production flows" and resulting revenue streams, meaning US financial firms are "central to global financial flows" (Schwartz, 2017, p. 277). The United States wields considerable power in determining which actors, whether states or companies, can access 
its market. Chinese companies like Alibaba have been working for years to expand into the United States (see e.g., Lim, 2019). In another indication of US structural power, Chinese platforms' continued growth within China and expansion internationally relies, in part, on their ability to access US financial markets (Fuchs, 2016; Jia \& Winseck, 2018).

An important indication of the structural power of the United States is its long history of shaping regulatory practices and standards internationally, including in regards to intellectual property where US industry actors play a critical role (Drahos, 2017, p. 252; Drahos \& Braithwaite, 2002). Copyright law determines how creative and artistic works like music, films, and books, along with software, can be accessed, used, and shared, while trademark law sets out the entities that can lawfully manufacture, distribute, advertise, and sell trademarked products. The United States, along with other industrialised actors like the European Union and Japan, considers intellectual property an economic and political priority because ownership of intellectual property rights is central to economic dominance in the modern globalised economy (Drahos \& Braithwaite, 2002; Sell, 2003).

The United States and China both endeavour to institute globally their preferred conceptions of internet governance, and the governance of technology more broadly that prioritise their economic, political, and security interests and favour their industry actors (see Min-hyung, 2019; Powers \& Jablonski, 2015). 1 This article argues that the US government, in cooperation with US industry, has interests in and the capacity to shape internet governance practices in China. In line with DeNardis (2014, p. 30), this article understands internet governance to include governance functions of private entities like Google or Alibaba controlling flows of information, typically through their private corporate policies. This article explores a littleexamined dimension of internet governance in China, the role of the US government shaping Chinese internet firms' regulation of intellectual property. Specifically, the article contends that the United States, with aligned interests between the US state and industry, exports its preferred standards and practices for the protection of intellectual property to China and institutes these within Chinese platforms. As a result, a dominant Chinese platform, Alibaba, has instituted USdrafted rules and standards to deal with the sale of counterfeit goods, a form of trademark infringement.

The article's case study is Alibaba's Taobao marketplace, the largest retail platform in China that western rights holders have long accused of facilitating the trade in counterfeit goods. Faced with pressure from the US government and key industry actors between 2008 and 2012, Alibaba significantly reformed Taobao's enforcement practices in line with demands from the United States. Alibaba's reform of Taobao raises an interesting puzzle. Why did a Chinese platform, particularly one as economically powerful as Alibaba, agree to enact specific regulatory reforms set forth by US companies? Further, what do Alibaba's reforms tell us about the capacity of the United States to shape internet governance practices in China?

To explain the relationship between the United States and Taobao, the article employs the concept of compliance-plus regulation, which it develops by drawing from regulatory theory and the socio-legal literature. In this concept, state and industry actors come together, cooperatively and through coercive state pressure to push platforms to exceed their legal responsibilities in the absence of legislation or legal orders. Compliance-plus regulation focuses attention on the interests of state and industry actors in undertaking the regulation and the state-industry relationship. While the US government's pressure on Alibaba was the impetus to push for Taobao's reform, the article finds that there were common economic interests among the parties involved. The United States has economic and political interests in protecting American 
intellectual property (see Drahos \& Braithwaite, 2002) and, more broadly, in shaping standards internationally in regards to internet governance (see e.g. Powers \& Jablonski, 2015). US rights holders want to expand their access to the large Chinese consumer market, meanwhile Alibaba not only wants to sell popular western brands through its market places, but also needs access to the US financial and consumer markets in order to expand outside of China. The United States thus exerts considerable structural power by controlling access to finance and to its market (in relation to China, see Fuchs, 2016; Jia \& Winseck, 2018).

To make its argument, the article analyses publicly available documents from the US government, US industry, and Alibaba relating to the reform of Taobao's enforcement practices between 2008 and 2018. The rest of the article proceeds as follows. The article introduces the concept of compliance-plus regulation and then gives a brief overview of Taobao. Next it describes US state and industry pressure on Taobao and then explains Taobao's reforms in response to this pressure. The article then examines Taobao's reforms as compliance-plus regulation resulting from coercive state pressure and the market leverage of the United States before providing a brief conclusion.

\section{COMPLIANCE-PLUS REGULATION}

In order to account for the state's privileging of certain (in this case, corporate) interests over others, the state is understood as embedded in the economic and social orders: the state and society mutually constitute one another (Underhill, 2003). Where there are competing interests among private actors, the state determines which actors are more authoritative and privileges certain policies over others (Hall, 1993, p. 288). These interdependencies among politics, society, and the economy are a key characteristic of regulatory capitalism, a framework that explains capitalism as a regulatory institution (see Braithwaite, 2008; Levi-Faur, 2005, 2017, p. 289). Regulation shapes and constrains the capitalist system and, in turn, capitalism creates demand for regulation (Levi-Faur, 2017, p. 289), which accounts for the transnational expansion of corporate regulatory efforts to protect intellectual property rights (Tusikov, 2017a, 2017b). Demand for regulation that accompanies capitalistic growth can bring together a hybrid arrangement of state and non-state actors (see e.g. Picciotto, 2011), as is characteristic of compliance-plus regulation.

Compliance-plus regulation builds upon research I have done elsewhere that identifies coercive state pressure underlying seemingly "voluntary" industry-led regulation undertaken by large US-based platforms (see Tusikov, 2017a). Compliance-plus regulation accounts for the role of state pressure, whether direct or indirect, in creating or facilitating private regulation, a similarity it shares with state-promoted private ordering (Bridy, 2011, 2015). From the regulatory and socio-legal literatures, the concepts of enforced self-regulation (Ayres \& Braithwaite, 1995; Braithwaite, 1982) and coerced self-regulation (Black, 1996; Bonnici, 2008) explain private actors' adoption of specific regulatory approaches, often in response to governmental pressure. However, coerced and enforced self-regulation generally focus on private actors regulating their own activities, often with public-interest benefits, such as corporate anti-pollution controls. In contrast, in compliance-plus regulation, the state directs, often using pressure, one set of private actors (platforms) to regulate on behalf of another set of private actors (multinational rights holders). While there may be a public benefit to anticounterfeiting programmes, such as reducing the sale of dangerous goods, the focus of this regulatory activity is the protection of US and European companies' intellectual property rights. 
The defining feature of compliance-plus regulation is coercive state pressure on private actors to exceed their legal requirements "voluntarily", that is, in the absence of legislation or formal legal orders (see Tusikov, 2017a, pp. 192-193). Corporate efforts to exceed voluntarily industry- or state-set rules are not unusual, especially when such efforts may burnish a company's reputation or provide a competitive advantage (see Haufler, 2001; Picciotto, 2011). Compliance-plus regulation, however, involves states pressuring private actors to adopt a particular regulatory approach that goes beyond their legal responsibilities in order to benefit other corporate actors.

Compliance-plus regulation is possible because of platforms' contractual terms-of-use agreements with their users that incorporate national laws and industry- or company-specific rules. Platforms can have a considerable regulatory capacity because, through these agreements, they have a quasi-legislative power to set and enforce rules over their users and a quasiexecutive power to enforce those rules through technical means (Belli \& Venturini, 2016, p. 4; see also Langenderfer, 2009; Belli, Francisco, \& Zingales, 2017). Importantly, platforms grant themselves the latitude to designate certain behaviour as "inappropriate" for their services even if that behaviour is lawful, meaning platforms can act as private arbiters of legality (see also Bridy, 2015; Tusikov, 2017a). By pressuring platforms to tap into their regulatory latitude, states can push platforms to exceed their enforcement responsibilities.

\section{TAOBAO}

Two of Alibaba's marketplaces, Taobao and Tmall, are of particular interest to US and European brands concerned about counterfeit goods. These marketplaces are a major part of the Alibaba ecosystem that also includes the Alibaba and 1688.com business-to-business marketplaces, a cloud storage business (Alibaba Cloud), and financial services (through its independent subsidiary, Ant Financial Services that operates the highly popular payment provider, Alipay). Formed in 1999, Alibaba is an economic success story in China: it has 699 million monthly users as of December 2018 and generated $\$ 39.9$ billion in 2018, 2 largely from its China-focused marketplaces, particularly Taobao and Tmall (Alibaba Group, 2018b).

Taobao, created in 2003, is the largest retail marketplace in China in which consumers and businesses sell a wide variety of goods. Taobao is the target of American anti-counterfeiting campaigns. For example, a prominent Washington, DC-based industry association, the International Anti-Counterfeiting Coalition (IACC), which represents well-known US and European companies from the apparel, pharmaceutical, and entertainment industries, argued that Taobao functioned "as a virtual, and 24-hour, 'trade exhibition' for counterfeiters and pirates seeking sources for illicit goods" (International Anti-Counterfeiting Coalition, 2011, p. 20).

Tmall, created, in 2008, is one of China's top business-to-consumer marketplaces in which merchants sell both Chinese and foreign brands. Tmall provides US and European brands a valuable entry point into the large Chinese marketplace. As of March 2018, Tmall had 150,000 brands on the platform of which 18,ooo were foreign brands from 74 countries, including luxury brands like Burberry and Dom Pérignon (Alibaba Group, 2018b).

While American companies often stress Taobao's ungoverned nature, Taobao is subject to legislation similar to platforms operating outside of China (see Ferrante, 2014; Friedmann, 2017). In 2010, China revised Article 36 of the Tort Law of the People's Republic of China (Tort Law of the People's Republic of China, 2010), which sets out the conditions under which 
platforms are liable for the infringement of intellectual property rights, and these conditions resemble those in the United States and Europe (see Ferrante, 2014). Taobao's terms-of-service agreements, like those of eBay, echo national laws that prohibit the sale, distribution, or advertisement of counterfeit goods and Taobao operates a notice-and-takedown programme that removes problematic sales listings once alerted by complainants (for Taobao's takedown process, see Alibaba Group, n.d.).

\section{STATE AND INDUSTRY PRESSURE ON TAOBAO}

The capacity for the United States to shape internet governance practices in China stems from its considerable structural power in which it can determine the conditions under which actors can access its market. Structural power "confers the power to decide how things shall be done, the power to shape frameworks within which states relate to each other, relate to people, or relate to corporate enterprises" (Strange, 1994, pp. 24-25). A key concern for the United States relating to China is the protection of intellectual property (see e.g. Tian, 2008). The United States exerts structural power in the protection of intellectual property rights, where it is the global leader in pushing for ever-stronger laws, standards, and enforcement practices (see Sell, 2010). In relation to China, US industry actors, supported by the US government, want to protect their valuable intellectual property rights. The US government also wants to ensure that it does not lose control of key technologies to Chinese companies, particularly those that may have a military application like artificial intelligence or robotics, which demonstrates why the US government strategically linked the protection of intellectual property to national security (see Halbert, 2016).

US rights holders were able to persuade the US government to pressure Alibaba into adopting their rules because there are aligned state-corporate interests regarding the protection of intellectual property rights (Drahos \& Braithwaite, 2002; Sell, 2003). This alignment of interests continues in relation to the digital economy. As explained earlier, the United States and other industrialised nations accord significant political and economic importance to the protection of intellectual property rights (Drahos \& Braithwaite, 2002; Sell, 2003). This is because economic benefits disproportionately flow to entities that own the intellectual property (e.g., California-based Apple) rather than those manufacturing the goods (e.g., China-based factories making iPhones) (see Kraemer, Linden, \& Dedrick, 2011, p. 4).

Since the 1970s, when the United States first elevated intellectual property rights to an economic priority, US rights holders and their trade associations have been central to the US government's campaign to push ever-tougher rules and standards for the global protection of intellectual property rights (Drahos \& Braithwaite, 2002; Sell, 2003). Corporate actors played important roles in persuading and pressuring foreign governments and corporations to adopt intellectual property laws that disproportionately favoured US industries, as well as those in a handful of other industrialised nations (see Sell, 2003). The US government formalised the role of prominent US companies as trade advisors to the government (Sell, 2003), thereby legitimising industry's push for tougher protection of intellectual property rights. A key industry player is the International Anti-Counterfeiting Coalition, which represents companies from the apparel, sporting goods, and pharmaceutical industries, as well as multinational companies based outside the United States, including Louis Vuitton Malletier and Chanel Inc.

The US government's trade body, the Office of the United States Trade Representative (USTR) played a central role in pressuring Alibaba into reforming Taobao's enforcement practices. The 
USTR operates the Special 301 Process, created in 1988 as part of the Omnibus Trade and Competitiveness Act (Omnibus Trade and Competitiveness Act, 1988). The Special 301 Process gives US companies the capacity to make complaints about countries that they contend provide insufficient protection of their intellectual property rights, and the US government can then impose trade sanctions against uncooperative countries. As part of the Special 301 Process, the USTR evaluates countries' protection of intellectual property, classifies targeted countries within a tiered system of watchlist countries, and directs countries to make specific legal and regulatory changes. 3

The Special 301 Process relies upon and primarily serves US industry interests. Industry provides resources for the "global surveillance network" required for the Special 301 country surveys, including industry data, analysis, and recommendations and, in turn, the US government provides the bureaucratic infrastructure that negotiates with, threatens, and sanctions targeted countries (Drahos \& Braithwaite, 2002, p. 107). The USTR's coercive pressure draws upon the structural power of the US market, as the USTR can withdraw access to the US market to sanctioned countries.

\section{BLACKLISTING TAOBAO}

The USTR provides a specific forum for US rights holders to target the online infringement of their intellectual property rights. In 2006, in response to industry lobbying, the USTR created a specific report, the Out-of-Cycle Review of Notorious Markets, to target problematic physical marketplaces, such as the Silk Market in Beijing, and online markets like the infamous Pirate Bay. Like the Special 301 Process, the Review of Notorious Markets depends upon industry data to determine which entities, websites, or platforms are failing to protect intellectual property rights in a manner that US rights holders consider adequate. The USTR pressures the entities it determines to be "notorious markets" to make specific changes to their enforcement practices, in line with US rights holders' demands, and, in turn, the US government may threaten targeted countries with trade sanctions to deal with their notorious markets.

While the USTR's Review of Notorious Markets exerts coercive pressure on its targets, the USTR acknowledges its report "does not reflect findings of legal violations" (Office of the United States Trade Representative, 2015b, p. 1). Rather, the notorious market list-and the Special 301 Process more broadly-is an aspirational project of regulatory standards and practices that rights holders argue are necessary to protect their intellectual property rights. For example, the IACC has submitted reports to the USTR that criticise Taobao's enforcement practices and proposes specific regulatory amendments (see e.g. International Anti-Counterfeiting Coalition, 2011).

The USTR is not unique in its use of a watchlist to monitor platforms and marketplaces, as the European Commission created its Counterfeit and Piracy Watch List in 2018 (see European Commission, 2018). While the European Commission's Watch List does not have the global scope of the USTR's Review of Notorious Markets or its coercive force, the European list is designed to raise consumer awareness and facilitate cooperation among EU trading partners and working groups regarding the online infringement of intellectual property rights (see European Commission, 2018). Like the USTR, the European Commission's Watch List identifies problematic online and physical marketplaces that are involved in the distribution of counterfeit goods. 4 The European Commission also operates an informal anti-counterfeiting enforcement agreement in regards to European online marketplaces that, like Taobao's enforcement agreement discussed in this article, was created through coercive governmental pressure (see Tusikov, 2017a). Launched in 2011 and updated in 2016, the European agreement sets non- 
legally binding principles for rights holders and marketplaces to address the sale of counterfeit goods (European Commission, 2011; see European Commission, 2016). Signatories include Adidas, Hermès, Lacoste, and Chanel and, in terms of marketplaces, eBay, Amazon, and Alibaba.

The USTR, based on rights holders' complaints regarding the sale of counterfeit goods, listed Taobao as a notorious market from 2008 to December 2012. In 2012, the USTR released Taobao from the notorious list, but following continued complaints about counterfeit goods from American and European rights holders, relisted the platform in 2017 where it currently remains (Office of the United States Trade Representative, 2018). 5

\section{TAOBAO'S RESPONSE TO US PRESSURE}

Alibaba's campaign to free Taobao from the USTR's notorious markets list provides an opportunity to study the internal regulatory efforts of platforms, which are not typically publicly disclosed. The USTR released Taobao from the blacklist in December 2012, following Alibaba's reforms to the marketplace's enforcement practices as detailed by Alibaba (see Spelich, 2012). Following Taobao's release, the USTR kept up the pressure on Alibaba with specific recommendations in its annual reports from US rights holders for continued reform of Taobao's enforcement practices. Since 2012, Alibaba has provided annual comments to the USTR's notorious market review.

The USTR demanded that Alibaba streamline or simplify Taobao's takedown process, and make takedowns more rapid (Office of the United States Trade Representative, 2012, 2015, 2016, 2018), and strengthen Taobao's cooperation with US rights holders (Office of the United States Trade Representative, 2012, 2014, 2015, 2018). Based on an analysis of Alibaba's reports to the USTR between 2012 and 2017 regarding Taobao, the article finds that Alibaba made three significant changes: it streamlined Taobao's takedown processes, it made takedowns more rapid, and it established informal enforcement partnerships with US rights holders. Alibaba's changes closely resemble the USTR's demands.

First, between 2012 and 2016, according to Alibaba, the platform "revamped and streamlined" its notice-and-takedown programme in relation to counterfeit goods "to provide rights holders a more user friendly platform” (Pelletier, 2017b, p. 6). Prior to 2012, Alibaba allowed complaints only in Chinese, and then in 2012 introduced an English-language complaint system (Spelich, 2012, pp. 3-7). Before 2016, Alibaba had two separate systems for making complaints: AliProtect (for AliExress, Alibaba.com or 1688.com) and TaoProtect (for Taobao and Tmall). In 2016, the platform merged these systems into one enforcement programme (Alibaba Group, 2017, p. 14).

Second, in addition to simplifying the complaint process, Alibaba responded to the USTR's demand to make its process more rapid. Before 2012, for example, Alibaba reported that it took between seven and ten days for Taobao to remove problematic sales listings (Spelich, 2012, p. 7). By 2015, the platform reported it took approximately two days to review takedown requests (Pelletier, 2017b, p. 6). In June 2017, Alibaba began using "enhanced algorithms and data modeling allow for greater automation in the analysis and processing of submissions" to reduce takedown requests to 24 hours during business days (Alibaba Group, 2018a, p. 4).

Third, Taobao began working directly with US rights holders on enforcement. A key example is 
the MarketSafe programme that was designed to "build a bridge between rights-holders and Alibaba" (The IACC MarketSafe Expansion Program, n.d.). In the summer of 2012, Taobao representatives approached the International Anti-Counterfeiting Coalition (IACC) with an "interest in partnering" with the trade association to address the sale of counterfeit goods (International Anti-Counterfeiting Coalition, 2012). The IACC-Taobao memorandum of understanding, announced in 2013, was launched in May 2014 as the MarketSafe Program. As of April 2017, the programme had 100 companies participating (International AntiCounterfeiting Coalition, n.d.). For Taobao, the programme introduces US and European rights holders to its enforcement practices with the goal of shifting these companies into working directly with Taobao.

MarketSafe's provides a "streamlined mechanism for expedited take-down actions" for listings from Taobao and Tmall for counterfeit goods (The IACC MarketSafe Expansion Program, n.d.) with IACC staff screening and coordinating the submission of takedown notice to the marketplaces (Pelletier, 2017a, p. 19). Most important for rights holders, the programme "shifts the burden of proof away from the brands and over to the sellers" (International AntiCounterfeiting Coalition, 2016a). MarketSafe members only need to send a complaint to Taobao for the removal of sales listings without providing proof of ownership of the trademark/s or copyright/s in question, or evidence of infringement (Pelletier, 2017a, pp. 18-20). The IACC lauds this measure as "more effective and efficient" as rights holders are "not required to provide evidence in support of their complaints" (International Anti-Counterfeiting Coalition, 2016b). According to the IACC, complaints through MarketSafe have a "100\% take-down rate" (The IACC MarketSafe Expansion Program, n.d.). MarketSafe, fully funded by Alibaba, provides rights holders with a simplified, rapid and efficient process to address complaints of counterfeit goods sales on Taobao and Tmall.

\section{TAOBAO ADOPTS COMPLIANCE-PLUS REGULATION}

The article's analysis of the USTR's reports and Alibaba's USTR submissions shows that Alibaba reformed Taobao's enforcement practices in line with US demands while the platform was blacklisted (see Spelich, 2012) and after its release (see Pelletier, 2017b). Overall, Taobao surpasses its legal requirements in terms of the speed and streamlined nature of its takedowns of problematic listings and in its reduced evidentiary requirements for MarketSafe members who do not need to provide proof of infringement or ownership of intellectual property before making complaints. Coercive state pressure paired with the latitude that platforms grant themselves to rapidly amend their terms-of-service agreements and enforcement practices enable compliance-plus regulation. Backed by the US government, US rights holders largely pushed a Chinese marketplace to adopt appropriately tough (that is, "US-style") enforcement measures.

Alibaba executives underline the significance of Taobao's enforcement changes in a report to the USTR, saying the platform has "established programs, technologies, and an approach to IP protection that goes far beyond our peers” (Pelletier, 2017b, p. 5). As a result, Taobao's enforcement practices, once the object of rights holders' condemnation, are remarkably similar to those of eBay in terms of the speed and streamlined nature of the takedown programmes and the reduced submission requirements for favoured rights holders (Tusikov, 2017a).

Corporate actors that voluntarily exceed their legal responsibilities are not unusual, particularly within industry self-regulatory programmes (see e.g. Haufler, 2001). There may be reputational or market advantages to adopt a compliance-plus position, such as a business voluntarily reducing its environmental impact (see van der Heijden, 2015). However, in Taobao's case, US 
companies, backed by the US government, demanded that Alibaba adopt a particular regulatory arrangement for their benefit, not that of Alibaba. US demands on Alibaba continue, particularly as the USTR relisted Taobao as a notorious market in 2017. In response to this second blacklisting, Alibaba critiqued the USTR for pressuring Alibaba to continue to augment its regulatory capabilities and reminded the USTR that Alibaba is a private entity. "No private company in the world," Alibaba wrote to the USTR, "can serve the role of a government, which is what the USTR is insisting Alibaba do in its report” (Alibaba Group, 2018c).

Compliance-plus regulation can impose serious risks on private actors, particularly when regulatory activities are undertaken to benefit other corporate actors. MarketSafe members can make takedown complaints without providing proof of infringement or ownership of the intellectual property in question, thereby shifting "the burden of proof" from rights holders to sellers (The IACC MarketSafe Expansion Program, n.d.). This change streamlined the complaint process for rights holders and made takedowns more efficient: a 100\% takedown rate for MarketSafe members. However, Alibaba, not rights holders, bears a "significant litigation risk if we inadvertently take down a [sales] listing that proves to be legitimate" (Pelletier, 2017a, p. 20). Despite the improvements to Taobao's enforcement practices, it is often difficult for platforms to determine the legality of products through sales listings as they typically do not have the legal or product-specific expertise to distinguish counterfeit from legitimate goods (see Tusikov, 2017a). Further, streamlined expedited takedown processes make it more difficult to detect bad-faith infringement complaints as platforms must act rapidly.

\section{COERCIVE PRESSURE}

While this article has concentrated on pressure on Alibaba from the US government and its key industry actors, the Chinese government also plays a role, particularly the State Administration for Industry and Commerce (SAIC) that is China's authority responsible for trademark administration. The SAIC has issued reports critical of Alibaba's enforcement practices to pressure the platform to improve its enforcement practices (see Friedmann, 2017). More broadly, the Chinese government has strengthened its protection of intellectual property rights, including passing the People's Republic of China E-commerce Law in 2019 that has provisions to address the online sale of counterfeit goods (People's Republic of China Electronic Commerce Law, 2018). China has long been the target of US pressure to strengthen its protection of intellectual property and, as a result of this pressure and in response to its domestic needs, China has introduced significant reforms (see Tian, 2008). However, the Chinese government also has, unsurprisingly, strongly criticised the USTR's blacklisting of Taobao and the USTR's repeated listing China as a "priority watchlist" country in the Special 301 reports. Following Taobao's blacklisting in 2012, Shen Danyang, a spokesman for the Ministry of Commerce, said the USTR's use of "ambiguous terms and no conclusive evidence or detailed analysis, [was] very irresponsible and not objective" (Alizila Staff, 2012). Similarly, in 2019, the head of China's National Intellectual Property Administration, Shen Changyu, said such criticisms of China's protection of intellectual property "lack evidence" and overlook the significant progress China has made in this area (Reuters, 2019).

The USTR's economic pressure on Alibaba was a central factor in pushing the company to comply with rights holders' demands. It is unlikely that US rights holders could independently induce a similar regulatory change in Alibaba through threats of litigation or promises of licensing deals for Tmall to sell their brands. State pressure is particularly important when private actors may be "reluctant governors" (Avant, Finnemore, \& Sell, 2010, p. 19) who may 
have conflicting interests in becoming regulators or when regulatory activities impose a significant financial burden on the actor.

Compliance-plus regulation underscores the importance of credible state pressure in compelling private actors to adopt specific regulatory goals or practices, or exceed their legal responsibilities. States, however, must carefully determine what situations and actors necessitate coercion. Coercion and its counterpart, reward, can be costly and states must be credible in their threats or promises of favour (Braithwaite \& Drahos, 200o). While a state may, for example, threaten trade sanctions, such actions can result in economic and political costs for those making threats (Drahos, 2017, p. 258). The United States monitors multiple countries and companies through its trade watchlists and while it infrequently imposes trade sanctions, the threat of sanctions can be sufficient pressure to motivate action (Drahos, 2017, p. 258). The USTR's ability to pressure notorious markets, however, may depend on whether the target has interests in operating legitimately or accessing the US market. The USTR, for example, has repeatedly blacklisted sites like The Pirate Bay, which provides unauthorised access to copyrighted movies, music, and software, but it has no ambitions to become a legitimate enterprise and is indifferent to its designation as a notorious market. Alibaba, in contrast, operates legitimately and is expanding internationally, particularly in regards to its marketplaces and financial services. In China, for example, Alibaba's Alipay is battling Tencent's WeChat Pay for control of China's mobile payments industry where they collectively dominate the market, and both companies are also expanding aggressively internationally (Y. Wang \& Armstrong, 2018b).

A key feature of compliance-plus regulation is that proponents repeatedly and coercively pressure private actors to set new or strengthen existing regulatory standards that exceed their legal responsibilities. Compliance-plus regulation is a process rather than an end goal. With the establishment of every new regulatory baseline, subsequent efforts focus on "ratcheting up" new tougher standards of enforcement, thereby resulting in ever-increasing standards (Sell, 2010; see also Bridy, 2015). As the Taobao case shows, compliance-plus regulation not only occurs through laws and international agreements, but also through coercive pressure on platforms to strengthen their regulatory practices in the absence of legislation or legal orders. As the USTR relisted Taobao as a notorious market in 2017, the USTR and US and European rights holders will continue to pressure Alibaba, although the nature and intensity of this pressure may change as the US-China trade dispute continues.

\section{POWER OF MARKET LEVERAGE}

As the Taobao case demonstrates, US rights holders have a powerful weapon in their partnership with the USTR, the leverage of the US market. Granting access to or denying companies the ability to operate in the United States is a powerful tool. Access to US financial markets was an important incentive for Alibaba to work with the USTR. While the USTR was blacklisting Taobao between 2008 and 2012, Alibaba was planning to conduct an initial public offering. Alibaba first considered plans to hold the offering in Hong Kong, but because of the Hong Kong market regulator's concerns with Alibaba's governance structure, Alibaba shifted to the United States (see Lin \& Mehaffy, 2016). In order to maximise the funds raised and the price of shares, Alibaba had to demonstrate to the US financial industry and US regulators that the company had solid financial and regulatory foundations by reforming Taobao's enforcement practices. Freeing Taobao from the USTR's blacklist removed a major impediment for Alibaba (see Javers, 2014). In September 2014, less than two years after Taobao's removal from the blacklist, Alibaba held a record-breaking US\$ 25 billion initial public offering. 
Related to the incentive of accessing the US market, there were also common economic interests between US and Chinese industry actors, despite the continued enmity of some western rights holders toward Alibaba. US and European rights holders want greater access to the Chinese market and to ensure that Chinese consumers are purchasing lawfully trademarked goods, and Alibaba's marketplaces, with their nearly 700 million users, are an ideal portal. In turn, Alibaba wants to increase Tmall's offerings of popular foreign brands, especially luxury goods. Alibaba's plans for Tmall and its international expansion rely, in part, on the platform's ability to demonstrate to foreign rights holders that it can govern its platforms effectively to address the trade in counterfeit goods.

The USTR's pressure on Taobao on behalf of multinational US and European rights holders continues the US government's long practice of setting rules and standards to benefit its economic interests and those of its industry actors. Since World War 2, the United States has been the "single most important actor in the spread of regulatory models", including in relation to intellectual property, and US multinational companies play an important role in this effort (Drahos, 2017, p. 252). Part of the campaign by the United States to export its preferred standards for the protection of intellectual property rights globally is to embed those standards within countries and, as this article argues, within non-US companies. Taobao's blacklisting is not an isolated case. The USTR has in the past blacklisted other prominent Chinese platforms, including the search engine Baidu and the e-commerce company JD.com, as well as platforms in other countries like Russia's VKontakte social media site (Office of the United States Trade Representative, 2011).

As the Taobao case shows, the United States wields considerable structural power as it can determine the actors that can access its market (Strange, 1994). Despite the growth of Chinese platforms and the economic power they wield in China, the structural power of the US market continues to be an important force shaping the internet, even within China. Baidu, Alibaba, and Tencent, along with other Chinese platforms seek international investors and list on US stock exchanges in order to attract US finance capital from investment banks and institutional investors (Fuchs, 2016, p. 34; Jia \& Winseck, 2018, p. 32). Chinese internet companies continue to hold initial public offerings in the United States, such as the online streaming platform iQiyi that raised US\$2.3 billion in $2018(\mathrm{Hu}, 2018)$. As a result, large Chinese platforms are "tightly integrated with a variety of sources of international finance capital" and increasingly rely upon foreign financial capital for their growth within China and international expansion (Jia \& Winseck, 2018, p. 31).

The desirability of the US financial market and the tight integration of Chinese platforms with international finance capital, especially that from the United States, means that the United States retains structural power in granting or denying access to its financial market. In January 2018, for example, the US government blocked a bid by Alibaba's Ant Financial to expand its payment service in the United States by acquiring MoneyGram International for US\$ 1.2 billion. The Committee on Foreign Investment in the United States (CFIUS), a multi-agency panel that brings together the Department of Defence, Department of Justice, and intelligence agencies to review foreign investment in the United States, denied the bid on national security grounds relating to a Chinese company possessing US consumer data (Y. Wang \& Armstrong, 2018a). CFIUS has also blocked other acquisitions of US technology by Chinese companies on national security grounds (see Blumental, Croley, \& Xu, 2018), and demanded that the Chinese gaming company Kunlun Tech sell the US-created gay dating app Grindr after the CFIUS barred Kunlun from accessing Grindr's personal data, which includes users' personal information like locations and HIV status, or sending that data to China (E. Wang, 2019). Chinese investors and start-ups 
are increasingly looking to Europe given the regulatory restrictions in the United States (see Y. Wang \& Armstrong, 2018a), but the US market remains attractive.

The United States remains an important force in setting standards and spreading norms that shape internet governance, particularly in relation to the regulation of intellectual property rights. From the early development of the internet, the United States has worked to embed standards that preference its economic, political, and national security interests through the internet, such as in relation to the commodification and free-flow of data (Powers \& Jablonski, 2015; see also Carr, 2016). This article demonstrates that the US government, working on behalf of multinational US and European industry actors endeavours to set standards for the protection of intellectual property within platforms, including platforms in China, in addition to setting standards through trade agreements (see Sell, 2010). Despite US fears about its declining hegemony and a shift in influence to China (see Min-hyung, 2019), the appeal of the US market remains strong (Schwartz, 2017).

The Taobao case is not simply about addressing the sale of counterfeit goods. In targeting Alibaba, US state and corporate actors were not only seeking to strengthen the enforcement practices of a single company, but also to influence regulatory practices within Chinese platforms generally and, more broadly, shape Chinese internet governance. By successfully pressuring Alibaba to adopt a compliance-plus approach, a Chinese platform has instituted the preferred standards of US rights holders: streamlined, rapid notice-and-takedown programmes and reduced evidentiary requirements for complainants. Given Alibaba's dominance within China in relation to its marketplaces, as well as its operation of multiple businesses, including payment services and cloud storage, Alibaba's US-influenced regulatory practices may become industry standards. Further, other Chinese platforms that want to access US financial markets may find the USTR's treatment of Taobao an instructive warning and amend their enforcement practices accordingly in line with US standards on the protection of intellectual property rights.

\section{CONCLUSION}

This article introduced the concept of compliance-plus regulation to explain a little-examined dimension of internet governance in China, the role of the US government in shaping Chinese internet firms' regulation of intellectual property. Compliance-plus regulation, which builds upon research I have done elsewhere (see Tusikov, 2017a) and draws from the regulatory theory literature, identifies coercive state pressure underlying seemingly "voluntary" industry-led regulation by platforms for the benefit of other corporate actors. The defining feature of compliance-plus regulation is coercive state pressure on private actors to exceed their legal requirements in the absence of legislation or formal legal orders with the goal of setting everincreasing standards of enforcement with each new round of pressure.

Compliance-plus regulation helps to explain why one of the largest Chinese platforms, Alibaba, has instituted US-drafted rules and standards to govern the protection of intellectual property rights. Following the wholesale reform of its enforcement practices, Alibaba's Taobao marketplace exceeds its legal responsibilities to regulate the sale of counterfeit goods. The USTR's economic pressure on Alibaba was a central factor driving Taobao's reform, but Alibaba and rights holders also have common economic interests. Alibaba wanted to access US financial markets and secure popular US and European brands for sale through its marketplaces. In turn, US and European rights holders, in addition to protecting their trademarks from counterfeiting, want to access China's large consumer market through which Alibaba's marketplaces provide an 
ideal entry point. With Taobao relisted as a notorious market in 2017, the USTR and rights holders will continue to pressure Alibaba. How that pressure may occur, the reactions of Alibaba and the Chinese government, and the broader implications for Chinese internet governance, particularly in the context of continuing geo-political tensions between the United States and China are important topics for future research.

Examining American pressure on Taobao usefully underscores the structural power of the US market (see Strange, 1994). Alibaba needed to demonstrate to US financial and regulatory authorities that it could effectively govern its businesses in order to have Taobao freed from the USTR notorious market list and before it could realise its intention of holding a successful initial public offering in the United States in 2014. Alibaba's efforts to access US finance capital highlights the dependence of Chinese platforms on finance capital from abroad, particularly the United States in order to expand within China and grow internationally (see Fuchs, 2016; Jia \& Winseck, 2018). American structural power is also evident in standard setting, such as in relation to protecting intellectual property rights (see Drahos, 2017) and denying Chinese companies access to the US market, as was the case with Alibaba's failed bid to acquire MoneyGram International in 2018. This article argues that US standard setting extends to influencing regulatory practices within Chinese platforms and, more broadly, shaping Chinese internet governance by embedding US-preferred standards for the protection of intellectual property rights.

While US state and corporate actors have successfully pressured Alibaba to make significant reforms to Taobao's regulatory practices, the dynamic of US structural power over Chinese platforms is not set in stone. US power currently remains strong in relation to American control over a disproportionate share of global production and related revenue streams, the draw of its large consumer market, and the key role played by its financial market in the global economy (Schwartz, 2017). However, with concerns in the United States about its declining hegemony (Min-hyung, 2019), and some scholars pointing to the rise of China's economic (and military) power (see Layne, 2018), the power dynamic between the countries may shift with as yet unknown effects on internet governance globally. Aside from the economic consequences from the US-China trade dispute, there are geopolitical implications as both countries are seeking technological dominance in areas including robotics, autonomous vehicles, and artificial intelligence (see Min-hyung, 2019). With continuing trade tensions, greater pushback from the Chinese government against US interference in Chinese internet governance is likely as both countries adopt protectionist measures that favour their domestic technology industries. As well, should the United States continue to restrict Chinese platforms' expansion into the United States, particularly in the financial services industry, as was the case with Alibaba's failed bid to acquire MoneyGram International, Chinese platforms will continue their expansion within Europe and Asia (see Detrixhe, 2019; Le Corre, 2019). The evolving US-China dynamics amid continuing geo-political tensions and the implications for internet governance globally are critical topics for future research. 


\section{REFERENCES}

Alibaba Group. (2017). Alibaba Group Platform Governance Annual Report 2016. Retrieved from Platform Governance Department website: https://www.alizila.com/wpcontent/uploads/2017/o6/Alibaba-Group-Platform-Governance-Report.pdf

Alibaba Group. (2018a). Alibaba Group 2017 Intellectual Property Rights Protection Annual Report. Retrieved from

http://azcms31.alizila.com/wp-content/uploads/2018/o5/Alibaba-Group-PG-Annual-Report-2 o17-FINAL_sm_final.pdf

Alibaba Group. (2018b, March 4). Alibaba Group Announced March Quarter 2018 Results and Full Fiscal Year 2018 Results. Retrieved from

https://www.alibabagroup.com/en/news/press_pdf/p180504.pdf

Alibaba Group. (2018c). Alibaba Group Point by Point Rebuttal of USTR Notorious Markets Listing of Taobao. Retrieved from

http://azcms31.alizila.com/wp-content/uploads/2018/o1/Alibaba-USTR-NMR-Pt-by-Pt-Rebut tal_FINAL.pdf

Alibaba Group. (n.d.). IP Protection Platform. Retrieved from https://ipp.alibabagroup.com/

Alizila Staff. (2012, January 18). Commerce Ministry Has Taobao's Back in USTR Spat. Alizila. Retrieved from https://www.alizila.com/commerce-ministry-has-taobaos-back-in-ustr-spat/

Avant, D. D., Finnemore, M., \& Sell, S. K. (Eds.). (2010). Who Governs the Globe? Cambridge: Cambridge University Press. doi:10.1017/CBO9780511845369

Ayres, I., \& Braithwaite, J. (1995). Responsive regulation: transcending the deregulation debate. New York: Oxford University Press.

Belli, L., Francisco, P. A. P., \& Zingales, N. (2017). Law of the Land of Law of the Platform: Beware of the Privatisation of Regulation and Police. In L. Belli \& N. Zingales (Eds.), Platform Regulations: How Platforms are Regulated and How They Regulate Us (pp. 41-64). Retrieved from http://bibliotecadigital.fgv.br/dspace/handle/10438/19402

Belli, L., \& Venturini, J. (2016). Private ordering and the rise of terms of service as cyberregulation. Internet Policy Review, 5(4). doi:10.14763/2016.4.441

Black, J. (1996). Constitutionalising Self-Regulation. The Modern Law Review, 59(1), 24-55. doi:10.1111/j.1468-2230.1996.tbo2064.x

Blumental, D., Croley, S., \& Xu, H. (2018). CFIUS and Chinese Investments in the United States-A Closed Door? [Article Reprint No. 2353]. Retrieved from Latham \& Watkins website https://www.lw.com/thoughtLeadership/CFIUS-chinese-investments-united-states-reprint

Bonnici, J. P. M. (2008). Self-regulation in cyberspace. The Hague: T.M.C. Asser Press.

Braithwaite, J. (1982). Enforced Self-Regulation: A New Strategy for Corporate Crime Control. Michigan Law Review, 8o(7), 1466. doi:10.2307/1288556

Braithwaite, J. (2008). Regulatory capitalism: how it works, ideas for making it work better. Cheltenham; Northampton: Edward Elgar. 
Braithwaite, J., \& Drahos, P. (2000). Global business regulation. Cambridge; New York: Cambridge University Press.

Bridy, A. (2011). ACTA and the Specter of Graduated Response. American University International Law Review, 26(3), 559-578. Retrieved from https://digitalcommons.wcl.american.edu/auilr/vol26/iss3/2/

Bridy, A. (2015). Internet Payment Blockades. Florida Law Review, 67(5), 1523-1568. Retrieved from http://scholarship.law.ufl.edu/flr/vol67/iss5/1

Carr, M. (2016). US Power and the Internet in International Relations: The Irony of the Information Age. London: Palgrave Macmillan. doi:10.1057/9781137550248

DeNardis, L. (2014). The global war for Internet governance. New Haven: Yale University Press.

Detrixhe, J. (2019, March 15). China's Ant Financial, thwarted in the US, is expanding rapidly in Europe. Quartz. Retrieved from https://qz.com/1570052/ant-financials-alipay-is-expandingrapidly-outside-of-china/

Drahos, P. (2017). Regulatory globalisation. In P. Drahos (Ed.), Regulatory Theory: Foundations and Applications (pp. 249-264). Canberra: ANU Press.

Drahos, P., \& Braithwaite, J. (2002). Information feudalism: who owns the knowledge economy?. New York; London: The New Press.

European Commission. (2011). Memorandum of Understanding. Retrieved from http://ec.europa.eu/growth/industry/intellectual-property/enforcement/index_en.htm\#Sale

European Commission. (2016). Memorandum of Understanding on the online sale of counterfeit goods [No. Ref. Ares(2016)3934515-26/07/2016]. Retrieved from http://ec.europa.eu/DocsRoom/documents/18023/attachments/1/translations/

European Commission. (2018). Counterfeit and Piracy Watch List [Commission Staff Working Document]. Retrieved from http://trade.ec.europa.eu/doclib/docs/2018/december/tradoc_157564.pdf

Ferrante, M. (2014). Online Counterfeit in China: Court Practice and Remedies against Infringing Websites. Section of Intellectual Property Law. Presented at the 29th Annual Intellectual Property Law Conference, Arlington, Virginia.

Friedmann, D. (2017). Oscillating from Safe Harbor to Liability: China's IP Regulation and Omniscient Intermediaries. In G. Frosio (Ed.), World Intermediary Liability Map, Mapping Intermediary Liability Trends Online. Oxford: Oxford University Press.

Fuchs, C. (2016). Baidu, Weibo and Renren: the global political economy of social media in China. Asian Journal of Communication, 26(1), 14-41. doi:10.1080/01292986.2015.1041537

Gilli, A., \& Gilli, M. (2019). Why China Has Not Caught Up Yet: Military-Technological Superiority and the Limits of Imitation, Reverse Engineering, and Cyber Espionage. International Security, 43(3), 141-189. doi:10.1162/isec_a_00337

Glasius, M., \& Michaelsen, M. (2018). Illiberal and Authoritarian Practices in the Digital Sphere. 
International Journal of Communication, 12, 3795-3813. Retrieved from https://ijoc.org/index.php/ijoc/article/view/8899

Halbert, D. (2016). Intellectual Property Theft and National Security: Agendas and Assumptions. The Information Society, 32(4), 256-268. doi:10.1080/01972243.2016.1177762

Hall, P. A. (1993). Policy Paradigms, Social Learning, and the State: The Case of Economic Policymaking in Britain. Comparative Politics, 25(3), 275. doi:10.2307/422246

Haufler, V. (2001). A public role for the private sector: industry self-regulation in a global economy. Washington, D.C.: Carnegie Endowment for International Peace.

Hopewell, K. (2018, May 3). What is 'Made in China 2015' and why is it a threat to Trump's trade goals? Washington Post. Retrieved from

www.washingtonpost.com/news/monkey-cage/wp/2018/05/03/what-is-made-in-china-2025-a nd-why-is-it-a-threat-to-trumps-trade-goals/?utm_term=.7a1ab702e427

Hu, K. (2018, December 28). Chinese companies flooded into the U.S. IPO market in 2018. Yahoo! Finance. Retrieved from https://finance.yahoo.com/news/chinese-companies-floodedu-ipo-183408925.html

International Anti-Counterfeiting Coalition. (2011). Submission of the International AntiCounterfeiting Coalition to the United States Trade Representative Special 301 Recommendations [Report No. Docket number USTR-2010-0037]. Retrieved from https://www.iacc.org/_downloads/keyissues/2011_IACC_Special_301_Report_Submission.pdf

International Anti-Counterfeiting Coalition. (2012). Submission of the International AntiCounterfeiting Coalition to the United States Trade Representative Special 301

Recommendations [No. USTR-2011-0021]. Retrieved from

https://www.iacc.org/_downloads/key-

issues/2012_IACC_Special_301_Report_Submission.pdf

International Anti-Counterfeiting Coalition. (2016a). Alibaba Group and International AntiCounterfeiting Coalition (IACC) Announce IACC MarketSafe ${ }^{\circledR}$ Expansion Program [Press Release]. Retrieved from https://www.iacc.org/press-release-iacc-marketsafe-expansion International Anti-Counterfeiting Coalition. (2016b). Submission of the International AntiCounterfeiting Coalition to the United States Trade Representative Special 301 Recommendations [No. USTR-2015-0022]. Retrieved from

https://www.iacc.org/_downloads/keyissues/IACC\%202016\%20SPECIAL\%20301\%20COMMENTS_FINAL.pdf

International Anti-Counterfeiting Coalition. (n.d.). Year in Review 2017 (pp. 1-8). Retrieved from

https://www.iacc.org/IACC\%202017\%20Year\%20in\%20Review/IACC\%202017\%20Year\%20in \%2oReview.pdf

Javers, E. (2014, September 16). Alibaba readies for post-IPO Washington office. CNBC. Retrieved from https://www.cnbc.com/2014/o9/16/alibaba-readies-for-post-ipo-washingtonoffice.html 
Jia, L., \& Winseck, D. (2018). The political economy of Chinese internet companies: Financialization, concentration, and capitalization. International Communication Gazette, 8o(1), 30-59. doi:10.1177/1748048517742783

Jiang, M., \& Fu, K.-W. (2018). Chinese Social Media and Big Data: Big Data, Big Brother, Big Profit?: Chinese Social Media and Big Data. Policy \& Internet, 10(4), 372-392. doi:10.1002/poi3.187

Kraemer, K. L., Linden, G., \& Dedrick, J. (2011). Who Captures Value in the Apple iPad and iPhone? Retrieved from http://pcic.merage.uci.edu/papers.htm

Langenderfer, J. (2009). End-User License Agreements: A New Era of Intellectual Property Control. Journal of Public Policy \& Marketing, 28(2), 202-2011. doi:10.1509/jppm.28.2.202

Laskai, L. (2018). Why does everyone hate made in China 2015? Council on Foreign Relations. Retrieved from www.cfr.org/blog/why-does-everyone-hate-made-china-2025

Layne, C. (2018). The US-Chinese Power Shift and the End of Pax Americana. International Affairs, 94(1), 89-111. doi:10.1093/ia/iix249

Le Corre, P. (2019). On China's Expanding Influence in Europe and Eurasia [Testimony to the US House of Representatives Foreign Affairs Committee, Subcommittee on Europe, Eurasia, Energy, and the Environment.]. Retrieved from https://carnegieendowment.org/2019/05/o9/on-china-s-expanding-influence-in-europe-and-e urasia-pub-79094

Letter to Probir Mehta, Assistant United States Trade Representative for Innovation and Intellectual Property [Office of the United States Trade Representative, Docket Number: USTR2016-2013, 2016 Special 301 Out-of-Cycle Review of Notorious Markets]. (2016, October 26). Retrieved from https://www.mema.org/sites/default/files/resource/MultiOrg\%20Letter\%20on\%20Alibaba\%20102616.pdf

Levi-Faur, D. (2005). The Global Diffusion of Regulatory Capitalism. The ANNALS of the American Academy of Political and Social Science, 598(1), 12-32.

doi:10.1177/0002716204272371

Levi-Faur, D. (2017). Regulatory capitalism. In P. Drahos (Ed.), Regulatory Theory:

Foundations and Applications (pp. 289-302). Retrieved from

http://press-files.anu.edu.au/downloads/press/n2304/pdf/ch17.pdf

Lim, S. (2019, March 6). Alibaba eyes US e-commerce market with Office Depot partnership. The Drum. Retrieved from https://www.thedrum.com/news/2019/o3/o6/alibaba-eyes-us-ecommerce-market-with-office-depot-partnership

Lin, Y.-H., \& Mehaffy, T. (2016). Open Sesame: The Myth of Alibaba's Extreme Corporate Governance and Control. Brooklyn Journal of Corporate, Financial \& Commercial Law, 1O(2), 437-471. Retrieved from https://brooklynworks.brooklaw.edu/bjcfcl/vol1o/iss2/5

Lv, A., \& Luo, T. (2018). Authoritarian Practices in the Digital Age: Asymmetrical Power Between Internet Giants and Users in China. International Journal of Communication, 12, 3877-3895. Retrieved from https://ijoc.org/index.php/ijoc/article/view/8543 
Meltzer, J. P., \& Shenai, N. (2019). The US-China economic relationship: A comprehensive approach. Retrieved from Brookings Institute website: https://www.brookings.edu/research/the-us-chinaeconomic-relationship-a-comprehensive-approach/

Min-hyung, K. (2019). A real driver of US-China trade conflict: The Sino-US competition for global hegemony and its implications for the future. International Trade, Politics and Development, 3(1), 30-40. doi: 10.1108/ITPD-02-2019-003

Muñiz, M. (2019, April 30). The Coming Technological Cold War. Project Syndicate. Retrieved from https://www.project-syndicate.org/commentary/us-china-technology-cold-war-bymanuel-muniz-2019-04

Office of the United States Trade Representative. (2011). 2011 Out-of-Cycle Review of Notorious Markets. Retrieved from https://ustr.gov/about-us/policy-offices/press-office/reports-andpublications/2011/out-cycle-review-notorious-markets

Office of the United States Trade Representative. (2012). Out-of-Cycle Review of Notorious Markets. Retrieved from

https://ustr.gov/sites/default/files/121312\%20Notorious\%2oMarkets\%2oList.pdf

Office of the United States Trade Representative. (2015a). 2014 Out-of-Cycle Review of Notorious Markets. Retrieved from

https://ustr.gov/sites/default/files/2014\%20Notorious\%20Markets\%20List\%20-\%2oPublished -o.pdf

Office of the United States Trade Representative. (2015b). 2015 Out-of-Cycle Review of Notorious Markets. Retrieved from https://ustr.gov/sites/default/files/USTR-2015-Out-ofCycle-Review-Notorious-Markets-Final.pdf

Office of the United States Trade Representative. (2016). 2016 Out-of-Cycle Review of Notorious Markets. Retrieved from https://ustr.gov/sites/default/files/2016-Out-of-CycleReview-Notorious-Markets.pdf

Office of the United States Trade Representative. (2018). 2017 Out-of-Cycle Review of Notorious Markets. Retrieved from https://ustr.gov/sites/default/files/files/Press/Reports/2017\%20Notorious\%20Markets\%20Lis t\%201.11.18.pdf

Omnibus Trade and Competitiveness Act. Pub. L. No. 100-418 (1988).

Pelletier, E. (2017a). Alibaba's Comprehensive Philosophy and Approach to IP Protection (Part II of letter dated October 2, 2017, from Eric C. Pelletier, Vice President, Head of International Government Affairs, Alibaba Group) (pp. 1-71). Retrieved from Alibaba Group website: https://www.regulations.gov/document?D=USTR-2017-0015-0020

Pelletier, E. (2017b). Comments Submitted by Alibaba Group - PUBLIC VERSION. Retrieved from Alibaba Group website: https://www.regulations.gov/document?D=USTR-2017-00150020

People's Republic of China Electronic Commerce Law. (2018). 
Picciotto, S. (2011). Regulating Global Corporate Capitalism. Cambridge: Cambridge University Press.

Plantin, J.-C., \& de Seta, G. (2019). WeChat as infrastructure: the techno-nationalist shaping of Chinese digital platforms. Chinese Journal of Communication, 1-17.

doi:10.1080/17544750.2019.1572633

Powers, S. M., \& Jablonski, M. (2015). The real cyber war: the political economy of internet freedom. Urbana: University of Illinois Press.

Reuters. (2019, April 28). China says criticisms on IP protection lack evidence amid trade spat. Reuters. Retrieved from https://www.reuters.com/article/us-china-trade-ip/china-sayscriticisms-on-ip-protection-lack-evidence-amid-trade-spat-idUSKCN1S4O2J

Schwartz, H. M. (2017). Elites and American structural power in the global economy. International Politics, 54(3), 276-291. doi:10.1057/s41311-017-0038-8

Sell, S. K. (2003). Private Power, Public Law: The Globalization of Intellectual Property Rights. doi:10.1017/CBO9780511491665

Sell, S. K. (2010). The Global IP Upward Ratchet, Anti-Counterfeiting and Piracy Enforcement Efforts: The State of Play [Research Paper No. 15]. Retrieved from American University Washington College of Law website: http://digitalcommons.wcl.american.edu/research/15/

Shen, H. (2016). China and global internet governance: toward an alternative analytical framework. Chinese Journal of Communication, 9(3). doi:10.1080/17544750.2016.1206028

Sottek, T. C. (2019, May 19). Google pulls Huawei's Android license, forcing it to use open source version. The Verge. Retrieved from https://www.theverge.com/2019/5/19/18631558/google-huawei-android-suspension Spelich, J. W. (2012). Comments Submitted by Taobao. Retrieved from Alibaba Group website: https://www.regulations.gov/document?D=USTR-2012-0011-0021

Strange, S. (1994). States and Markets (2nd ed.). New York: Continuum.

The IACC MarketSafe Expansion Program. (n.d.). Retrieved from

https://www.iacc.org/MSE/MarketSafe_MSE\%20Fact\%20Sheet\%206.18.2018.pdf

Tian, D. (2008). The USTR Special 301 Reports: an analysis of the US hegemonic pressure upon the organizational change in China's IPR regime. Chinese Journal of Communication, 1(2), 224-241. doi:10.1080/17544750802288032

Tooze, A. (2019, April 4). Is this the end of the American century? London Review of Books, pp. $3-7$.

Tort Law of the People's Republic of China. Pub. L. No. PRC Presidential Order No. 21 (2010).

Tusikov, N. (2017a). Chokepoints: global private regulation on the Internet. Oakland, California: University of California Press.

Tusikov, N. (2017b). Transnational Non-State Regulatory Regimes. In P. Drahos (Ed.), Regulatory Theory: Foundations and Applications (pp. 339-353). Retrieved from 
https://press-files.anu.edu.au/downloads/press/n2304/pdf/book.pdf

Underhill, G. R. D. (2003). States, Markets and Governance for Emerging Market Economies: Private Interests, the Public Good and the Legitimacy of the Development Process.

International Affairs, 79(4), 755-781. doi:10.1111/1468-2346.00335

van der Heijden, J. (2015). What Roles are There for Government in Voluntary Environmental Programmes?: What Roles for Government in Voluntary Environmental Programs? Environmental Policy and Governance, 25(5), 303-315.doi: 10.1002/eet.1678

Van Dijck, J., Poell, T., \& De Waal, M. (2018). The Platform Society. Public values in a connective world. New York: Oxford University Press.

Wang, E. (2019, May 13). China's Kunlun Tech agrees to U.S. demand to sell Grindr gay dating app. Reuters. Retrieved from https://www.reuters.com/article/us-grindr-m-abeijingkunlun/chinas-kunlun-tech-agrees-to-u-s-demand-to-sell-grindr-gaydating-app-idUSKCN1SJ28N

Wang, Y., \& Armstrong, P. (2018a, January 8). U.S. Block Of Moneygram Sale Paves The Way For China Trade, Investment Showdown. Forbes. Retrieved from https://www.forbes.com/sites/ywang/2018/01/o8/u-s-blockof-moneygram-sale-paves-the-way-for-china-trade-investment-showdown/\#798f20c764ba

Wang, Y., \& Armstrong, P. (2018b, March 28). Is Alibaba Losing to Tencent In China's TrillionDollar Payment War? Forbes. Retrieved from

https://www.forbes.com/sites/ywang/2018/o3/28/is-alipay-losing-to-wechat-in-chinas-trillion -dollar-payment-war/\# eofe4df88220

White House. (2019). Execuive Order on Securing the Information and Communications Technology and Services Supply Chain [Executive Order]. Retrieved from https://www.whitehouse.gov/presidential-actions/executive-ordersecuring-information-communications-technology-services-supply-chain/

\section{FOOTNOTES}

1. Despite operating in different political environments, platforms in China and the United States both have commercial practices that prioritise the accumulation and monetisation of users' personal data through advertising, minimise user privacy, and enroll industry, whether through incentives or coercive state pressure (see Fuchs, 2016; Glasius \& Michaelsen, 2018; Jiang \& Fu, 2018; Lv \& Luo, 2018).

2. All figures in US dollars.

3. These tiers, in order of seriousness are: priority foreign country, priority watch list, and watch list. See the USTR's Special 301 Reports.

4. In 2018, for example, the European Commission singled out seven marketplaces like the Indonesian-based Bukalapak and, while it did not blacklist Alibaba, it warned the platform, along with Amazon and eBay, that "further progress is needed" to address the online sale of counterfeit goods (European Commission, 2018, p. 26).

5. While the IACC did not publicly call for Taobao to be relisted as a notorious market, two trade associations, the American Apparel and Footwear Association and the French anti- 
counterfeiting group Union des Fabricants (Unifab) called on the USTR to relist Taobao. These associations complained that despite Alibaba's claimed enforcement improvements, "we have seen little evidence that there has been any noticeable change on the Alibaba platforms themselves" (Letter to Probir Mehta, Assistant United States Trade Representative for Innovation and Intellectual Property, 2016). 